\title{
NON-DISCRIMINATION AND NON-STIGMATISATION AS GLOBAL BIOETHICAL PRINCIPLES: INTRODUCING AN OVERDUE PROTESTANT DISCUSSION WITH UNESCO
}

Adriaan L. Rheeder The Unit for Reformational Theology and the Development of the South African Society Faculty of Theology North-West University

\begin{abstract}
Until now there has been no official dialogue between UNESCO and the Protestant faith tradition regarding article 11 of the UDBHR; therefore, this article forms a first and preliminary introduction to the discussion. The purpose of this discussion is to formulate a theological ethical foundation for article 11 of the UDBHR. It is important from Protestant and UNESCO perspectives to formulate an ethical foundation. On the one hand, this conversation contributes to strengthening the credibility of the declaration, while on the other hand, it offers this instrument a necessary religious status. It is clear that article 11 of the UDBHR states that non-discrimination and non-stigmatisation are two principles that have been accepted by the world community and should to be promoted in the context of health. These two global bioethical principles are recognised and accepted by Protestant social ethics in the faith framework of the covenant and can, therefore, be promoted by the Protestant community in the context of health in South Africa and the world.
\end{abstract}

Keywords: Discrimination; Stigmatisation; Global bioethics; UNESCO;

Protestant; Covenant

\section{Introduction}

In 2005, the Universal Declaration of Bioethics and Human Rights (hereafter UDBHR) of the United Nations Educational, Scientific and Cultural Organization (hereafter UNESCO) was unanimously accepted by all member states (IBC 2010:9; Ten Have and Jean 2009:17). This is the only bioethical instrument that has been accepted by all states of the world, including South Africa. This fact makes this document a very powerful instrument for guiding and motivating states, individuals, groups and communities in pursuing the common good in and between countries in the context of medicine, life sciences and associated technologies. This global representativeness of the UDBHR justifies a theological discussion; therefore, this study forms part of a broader project focusing on the theological aspects of the UDBHR (see Rheeder 2017a; 2018; 2019a; 2019b).

The study in particular seeks to provide theological-ethical grounding for UNESCO's article 11 of the UDBHR from a Protestant perspective. The title of the article is "Non- 
discrimination and non-stigmatization" and the article reads (UNESCO 2006), "No individual or group should be discriminated against or stigmatized on any grounds, in violation of human dignity, human rights and fundamental freedoms."

The foreword of the UDBHR states that the ethical foundation is found in "universal principles based on shared ethical values" (UNESCO 2006). With this statement, UNESCO assumes that these global principles are also supported by Protestant social values, without indicating theological grounds for this. However, Macaleer (2014:2430) and Rusthoven (2014:201-203) clearly show that no Protestant ethicist has yet given thorough attention to a theoretical grounding of modern global bioethical principles. In his book (or dissertation), The New Testament and bioethics: Theology and basic bioethics principles, Macaleer (2014:ix- $\mathrm{x}$ ) deals with Protestant theological grounding of the four universal bioethical principles of Beauchamp and Childress (autonomy, beneficence, maleficence and justice). He comments on these principles, saying, "As outlined by Beauchamp and Childress, these principles are based on what they call the common morality. Thus, the principles have no specific theological foundation; this book attempts to give those principles a Scriptural foundation."

The problem statement of this study is that no theological grounding exists for the global principles of the UDBHR from a Protestant perspective. Macaleer (2014:i) confirms this problem, saying, "Yet, few Protestant authors have connected the New Testament to some of the most common bioethics principles used in healthcare today." This analysis is a humble beginning.

Why would a theological foundation be important? From UNESCO and Protestant perspectives, it is essential to provide a theological basis for this global bioethical principle. These two perspectives will be briefly discussed because they are dealt with in more depth and in different variations in other studies (see Rheeder 2017a; 2018; 2019a; 2019b).

From a UNESCO perspective, it is important that global bioethical principles should be supported by all religions of humanity (as accepted by article 14 of the UDBHR) to give credibility and practical utility to the universal character of the declaration. During the development of the declaration, consultations took place with Islam, Confucianist, Buddhist, Hindu, Roman-Catholic and Jewish faith traditions (IBC 2005:6-7; Ten Have and Jean 2009:31; Gallagher 2014:135), but not with the Protestant faith tradition (Tham 2014:2-3). This exclusion is problematic from the perspective of global acceptance. According to Rawls (1993:134), a system of universal values will only be truly internalised when it can be motivated from an own religious point of view. Habermas (2012:324) supports the notion that religious citizens can only accept the secular legitimation of the community on the premises of their own faith (see also Pirner 2016b:16-18). The philosopher Charles Taylor (2007:702) also recognises the possibility and desirability of an own Christian foundation for universal principles. UNESCO (2019) cherishes this line of philosophical thought when it stresses the fact that global bioethical principles should find their roots in the cultural, philosophical and "religious bedrocks of various human communities". The formulation of a Protestant theological bedrock could contribute to greater acceptance and credibility of the UDBHR in South Africa, as well as in the global community. In this way, the exclusion of the Protestant community in the discourse could be addressed. UNESCO recognised the importance of the own religious point of view and the necessity of the broadest possible 
religious support for the principles of the UDBHR. Therefore, the organisation published the research series, Advancing global bioethics, through different Chairs in Bioethics around the world, presenting the perspective of Protestantism to improve the inclusiveness of the declaration (Tham 2017:xxiv). An example of an article that has received attention is article 14, "Religious perspectives on social responsibility in health" (see Tham, Durante and Gómez 2018).

However, it is also important from a Protestant perspective to formulate a theological grounding for the principles in the UDBHR to give the necessary religious status to a secular instrument within a large grouping of the global Christian community. Macaleer (2014:10) declares, "The question facing Protestants who want to find their bioethics not in common morality but in Scripture is what does the Scripture have to add to the discussion of bioethics?" The well-known Protestant bioethicist James Childress (2002:190) is correct when he states that Protestants favour direct appeals from Scripture. In general, Protestant people are referred to as "people of the Book", which indicates the importance of the Bible. This means that Scripture is recognised to be authoritative and is described as the Word of God (Macaleer 2014:8). A close connection between Scripture and global ethics is assumed. Habermas (1999:226) is correct when he claims that human rights are human social constructs that should not be confused with facts or eternal truths. That is why Vorster (2015:109) states, from a Protestant perspective, the opinion that the second commandment (Ex 20:4-6) declares the Bible as the primary source of ethical knowledge; therefore, he says, the Bible should serve as "die toetssteen van alle etiese kodes en handelinge" ["the acid test for all ethical codes and acts"]. Protestantism is not negative towards human ethical reasoning (Vorster 2015:37-59), but is of the opinion that natural law cannot serve as the only basis for a complete Protestant ethics (Douma 1997:70). The best way to gain insight into ethics, is through dialectic of natural law and the Bible, with primary focus on Scripture, forming in this manner a complete social ethics (Douma 1997:56; Pirner 2016a:335; Nullens and Volgers 2010:63).

Regarding the need for this study, it should be noted that the UDBHR, including article 11, appears to have had little or no impact as a frame of reference and a set of guiding principles in South Africa (Langlois 2013:154). A possible reason is the fact that South Africa is a predominantly Protestant country where there has been no dialogue about the religious roots, bedrock or foundation of the declaration. In addition, discrimination and stigmatisation in the health environment takes place in various areas and forms in the South African community. Two examples should prove the point. An empirical study by Duby et al. (2018:1) arrived at the following conclusion: "Female sexual workers, men having sex with men and people who use drugs described their experiences of stigmatisation, and of being made to feel guilt, shame and a loss of dignity as a result of the discrimination by healthcare providers and other community members." From a global perspective, the South African Human Rights Commission (SAHRC 2018) records the following: "In another incident, a migrant woman was forced to give birth at a bus station after allegedly being denied access to two hospitals in Gauteng province. Such denials of care violate rights. They have a gendered, racial and class impact, with poor, black women bearing the brunt of this discrimination." Providing a theological grounding could contribute to the internalisation of this global bioethical principle by the Protestant community in South Africa, thus promoting the UDBHR in 
general and article 11 in particular in South Africa (and possibly the global community). The UDBHR and the theological foundation could be used as an authoritative bioethical source in combating discrimination and stigmatisation in the health sector in South Africa.

Protestantism is the collective name for various religious Christian traditions that emerged from the $16^{\text {th }}$ century onwards. It is one of three major associations of religious thought and belief in Christianity, the other two being Catholicism and Orthodoxy (Van Leeuwen 2014:431). There are between 800 million and 1 billion Protestants globally among approximately 3 billion Christians (Pew Research Center 2020). Nowadays, a large diversity of moral viewpoints is found in Protestantism and it is almost impossible to state a universal Protestant position on any bioethical challenge. As a result, theologians have to focus on one Protestant position or pinpoint a few Protestant positions with respect to a specific bioethical problem (Childress 2002:187). The approach in this study is not associated with any particular theological tradition in Protestantism, specifically to promote the universality and credibility of article 11 as far as possible in Protestantism.

One should guard against a biblicist use of the Bible. In his medical ethics, Douma (1997:41) also states that biblical themes, and not isolated texts, should be used in the search for answers to bioethical issues (cf. also Vorster 2017:123). This study will focus on the theme of the covenant of God as the foundational Protestant perspective on article 11 of the UDBHR. The research problem addressed in this study is the fact that no academic discussion exists between UNESCO and Protestant social ethics with regard to specifically article 11 of the UDBHR. The aim of this study is to initiate a dialogue between Protestant social ethics and UNESCO on article 11. The central theoretical statement of this study is that article 11 of the UDBHR can be broadly supported by the Protestant scriptural concept of the covenant of God.

The method that will be followed, will firstly be to analyse and interpret article 11 from a UNESCO perspective, after which this conceptual analysis and interpretation will be assessed and grounded in the light of Scripture.

\section{Global principle}

Next, attention will be paid to the meaning of the concepts "non-discrimination" and "non-stigmatisation" as universal bioethical principles. In another essay, "A global bioethical perspective on organ trafficking: Discrimination, stigmatization and the vulnerable", I made an in-depth analysis of article 11 after which I applied the content of the global bioethical principle to the problem of global organ trafficking (Rheeder 2017b; see also Rivard 2009:191; IBC 2014:5-6). Without repeating what has already been written, this paragraph will deal with the meaning of article 11 of the UDBHR in summary under three headings namely, foundation, non-discrimination and nonstigmatisation.

\section{Foundation}

Firstly, article 11 must be read together with article 1.1, which indicates the scope of the declaration. It means that the prohibition of discrimination and stigmatisation does not imply all possible contexts, but is specifically aimed at "ethical issues related to medicine, life sciences and associated technologies as applied to human beings, taking 

into account their social, legal and environmental dimensions" (UNESCO 2006; see also Rivard 2009:191-192; IBC 2014:3). Secondly, referring directly to the previous point, according to article 1(2), it is expected that the principles of non-discrimination and nonstigmatisation should be respected and promoted by the state as well as the non-state environment in all decisions and practices (Rivard 2009:192; IBC 2014:6). One could argue that this includes religious organisations and the church.

Thirdly, the concept of human dignity (art. 3) functions as the basis for the global principles of non-discrimination and non-stigmatisation (art. 11). This premise is confirmed in article 2 which indicates that the UDBHR contains a universal framework of principles with the aim of promoting human dignity (cf. also UNESCO 2006, art. 26). When actions discriminate against people or when populations are stigmatised, their human dignity is seriously violated (Garrafa 2016:909; Guessous 2014:150; UNESCO 2011:10). In the last place, the principle of equality (art. 10), together with human dignity, forms the foundation of article 11 (UNESCO 2006). Fighting discrimination and stigmatisation within the health environment is the affirmation of the equality of all people. Discrimination and stigmatisation are the opposite of equality (Guessous 2014:139-140, 150; IBC 2014:8; UNESCO 2008:48).

\section{Non-discrimination}

In summary, UNESCO in the UDBHR broadly understands the following under the concept non-discrimination (Garrafa 2016:910; Guessous 2014:140-141; Rivard 2009:189, 192, 196; Rheeder 2017b:22-23; UNESCO 2006; UNESCO 2008:48; Ten Have 2016:101-103):

- The UDBHR does not itself present a definition of discrimination but does state in article 14 that attainable health is a fundamental right of every human being "without distinction of race, religion, political belief, economic or social condition ...".

- The phrase "any grounds" in article 11 apparently wants to elaborate on article 14 and therefore most commentators of the UDBHR refer to the International Convention on the Elimination of All Forms of Racial Discrimination of the United Nations (1965) as well as the Convention on the Elimination of All Forms of Discrimination against Women (United Nations 1979) in establishing an understanding of non-discrimination. Most interpreters understand discrimination in the UDBHR as an act that:

○ unlawfully discriminates, excludes, includes, restricts or prefers,

$\circ$ on the basis of race, colour, descent, national or ethnic origin,

o with the aim or consequence of restricting or destroying equal treatment of persons, human rights and fundamental freedoms,

o within the political, economic, social, cultural or any other public context.

- Within the context of health, special mention must be made of the concepts of exclusion and inclusion as noted in the above discussion:

- On the one hand, people or populations are excluded from medical intervention and care (because of perceived inferior status),

- On the other hand, people or populations are included in certain circumstances on the basis of the denial of their human dignity. In this regard, the use of poor people as research participants can be mentioned. 


\section{Non-stigmatisation}

In summary, UNESCO in article 11 understands the following under the concept nonstigmatisation (Garrafa 2016:913; Guessous 2014:141, 144; IBC 2014:7-8; Rheeder 2017b:23; Rivard 2009:194; UNESCO 2003; UNESCO 2008:48):

- It should be mentioned that the UDBHR is the first and currently the only bioethical human rights instrument that uses the concept of non-stigmatisation within the health environment.

- Unlike the concept of non-discrimination, for which there is an entrenched definition in article 14, there is no explanation of the meaning of non-stigmatisation in the UDBHR itself.

- Commentators on article 11 refer to English dictionaries (Oxford English dictionary online, Encyclopedia Britannica and Merriam-Webster online dictionary) in the formulation of a definition. Stigmatisation can be understood as follows:

- It is an act that formally or informally gives individuals or populations, because of their physical, psychological, moral, medical or socially challenging circumstances, a derogatory name or label such as "whore", "homo", "junkie" or "leprous" (to use a biblical example).

- The reason for the derogatory labelling is to characterise the person or group negatively and indicate their inferiority. The derogatory term suggests to the community that the person or group is useless, dangerous, dirty, full of anger and/or destructive.

- Stigmatisation is not an independent concept. The greater purpose of derogatory naming is to justify discriminatory action against a person or group. "Discrimination is the manifestation of stigma", is the opinion of the International Bioethics Committee, which is an official advisory body of UNESCO. Because a person is a "whore", "homo" or "junkie", they do not deserve the same respect or medical intervention as people in other or more acceptable circumstances or lifestyles.

Article 11 as a global principle clearly states that no discrimination against or stigmatisation of any person is allowable ("No individual or group should be discriminated against or stigmatized").

Subsequently, a covenant perspective on the global principles of non-discrimination and non-stigmatisation will be suggested.

\section{Covenantal perspective}

From the discussion of article 11 of the UDBHR, it has become clear that the international community embraces the authoritative global bioethical principles of nondiscrimination and non-stigmatisation, which as human rights give expression to human dignity and equality. I will now discuss whether global ethics, human dignity, nondiscrimination and non-stigmatisation are biblical concepts that could also be supported by the Protestant tradition in the context of health. If these principles are to be accepted, what would the biblical grounds be?

The concept of the covenant is a prominent theme in Scripture. Vorster (2017:138) says the biblical doctrine of the covenant offers a Christian-social ethics that can serve as foundation for human rights concepts. According to Childress (2002:191), human 
covenants, such as those in medicine, can mirror and reflect God's covenants. Both Macaleer (2014:108-120) and Rusthoven (2014:127-214) apply the covenant doctrine to a Protestant (reformed) grounding for the bioethical principles of human dignity, benefit and harm and equality. Protestant theology sees the covenant as a paradigm of deeds of God in creation, of a relationship with humanity, and, eventually, of salvation and ethical obligations (Macaleer 2014:51).

A distinction can be made between the "universal covenant" (also called the "work covenant", "covenant of nature" or "creation covenant") and the "covenant of grace". With the universal covenant God established a relationship with the human race that included gracious promises and obligations. This relationship with creation and humanity served as an expression of God's love and universal grace (Vorster 2017:139). God established the universal covenant with Adam and Eve when He created them in his image. Osterhaven (2017:215) writes, "Having created humans in his own image as free creatures, God entered into covenant that he might bestow on Adam and Eve further blessing." The fact that they were image bearers made a relationship between God and people possible. The covenant of grace came into being with the coming of the promised Messiah. Adam and Eve unilaterally broke the universal covenant during the fall into sin (Gn 3). After the fall, humanity did not want a relationship with God, which meant only God could initiate and restore the covenant. God did indeed restore the relationship with humanity by establishing the covenant of grace with Abraham (Gn 12, 17; Macaleer 2014:112-114). This covenant was a turning point in the history of salvation because God established a covenant with a segment of humanity, namely the covenant people of Israel (covenant of grace). This nation would be different from the other nations of the world, living under the direct rule of God according to covenant laws, and promised by God salvation by the Messiah (Vorster 2017:140). The appearance of the promised Christ was the visible confirmation of the covenant of grace (Lk 22:20). By his death and resurrection, Christ brought redemption to humanity (Macaleer 2014:108-110). This redemption restored brokenness and broken relationships, and placed humans, by their faith in Christ, in a new relationship with God (2 Cor 5:17-21). Through faith in Christ, humans can now come to God in the relationship as it was meant and created before the fall. The new covenantal relation with God extends to marital relationships (Eph 5:2), to families (Eph 6:1-4) and labour relations (Eph 6:5-9). In the light of this new relationship with God, in which evil has been overcome by Christ (Col 2:15), Vorster (2017:141) says, "Social relations characterised by selfishness, oppression, discrimination, exploitations and other forms of hostility, due to the evil, are transformed."

In the covenant of grace, Jesus' command to "follow me" appears repeatedly (Mt 8:22, 9:9; Mk 2:14; Lk 5:27; Jn 1:43). To follow Christ or walk in his footsteps indicates to follow his good actions or covenant ethics (1 Pt 2:21-24), particularly in the context of healing and health (1 Pt 2:25).

Firstly, according to VanDrunen (2009:33), the universal covenant of God with the world in Genesis 1-11 forms the background for understanding a global bioethics. The following statement by Mackler (2014:397) is his understanding of the interrelation between the universal covenant of God and the UDBHR: "Modern thinkers increasingly came to see in the Bible's account of having God begin humankind with but one pair of people an early intuition of the truth that all ethics is necessarily universal. Put 
symbolically, one Divine Parent meant that all human beings have familial obligations to one another."

Scripture confirms the beginning of global instructions with the purpose of governing the diverse and broken human existence after the fall into sin. König (2010:113-114) and Van Wyk (1998:176) indicate that early biblical narrative (Gn 1-11) authorises universal human history (before the calling of Abraham) and should be understood as follows: On the one hand, God is universally involved or in a covenant with all humanity or all living beings according to Genesis 9:16; on the other hand, this section deals with matters that all humanity has in common (Kelly, Magill and Ten Have 2013:15; Vorster 2017:139). The manner of involvement and intercommunity, which is not explicitly mentioned by König and Van Wyk, is explained in VanDrunen's book Bioethics and the Christian life (VanDrunen 2009:31-33): "Genesis 4:15 and 9:6 are particularly relevant. In both of these texts God ordained a system of human justice not as the sole possession of those who believed in him but as the common possession of the human race."

The universal covenant with God that is used as the basis for global bioethics can also be Christologically motivated. In Matthew 7:12, Jesus recommends a guideline not only found in the Bible but also found in almost all religious traditions (Østnor et al. 1995:19). In this way, Scripture wants to indicate that global principles exist as shared values and should be pursued. Early biblical narrative (Gn 1-11) and Christology indicate that God will bestow instruments of authority in the form of universal codes such as the UDBHR in order to safeguard humans and creation against evil and to foster well-being (Vorster 2007:108). The universal covenant and Christology as basis for global bioethics as well as universal shared social ethics, are supported throughout the Bible. The truth that all people are created in the image of God (Gn 9:6) points to the fact that all people have a responsibility towards each other (Macaleer 2014). Global responsibility is based on the acceptance of the view that the whole world, including all of humanity, are morally brothers and sisters of each other (Am 1:9) with the common purpose to promote peace and stability. Because God is good to all people (Mt 5:44-46; Ps 145:9), the human being is directed to be good to all people (Gl 6:10). Humanity has to foster the common good (Douma 1990:54). This could be done by means of global bioethics or the acceptance of universal shared values (Is 32:17; Ps 85:11; Ja 3:18; Van Wyk 1991:259) in a diverse and secular world (Jr 29:4-7; Rm 12:18). This argument leads to the conclusion that Protestant ethics may expect global bioethics as articulated in the UDBHR.

It has been demonstrated that the UDBHR relates human dignity and equality to the principles of non-discrimination and non-stigmatisation. Secondly, all of these concepts can be motived from Scripture by the fact that the human as covenantal being is created in the image of God. God connected humanity with his own nature and characteristics when He created the human being in his image (Gn 1:26-27). The fact that humanity man and woman - is created in the image of God, indicates the anthropological position of the human being and has the following implications (Bridger 1995:351-352): Being created in the image of God, reveals human dignity. In the hierarchy of existence, the Trinity manifests the uppermost form of existence and dignity (Higginson 1995:98); therefore, God is celebrated in Revelation 4:11 as the ultimate worthy one (Heb 3:3). If God is supreme dignity and humanity is created in his image, then the human being has obtained, but definitive, worth (Mt 6:26; 2 Pt 1:4). "If God can become a man, how great 
can man be?", Morphew (2015:loc 679) submits tellingly. All people are equal (Bridger 1995:352-353). The Trinity as persons-in-relationship, in which the Father, Son and Holy Spirit are co-equal to each other (Rm 9:5; 2 Cor 3:17-18; Mt 28:19), is regarded as a social model for humanity (Bridger 1995:352-353; Lorenzen 2009:288). Because all people are created in the image of God, all people are equal to each other (Macaleer 2014:172; Hollinger 2008:230). The equality of all people is confirmed throughout the covenant message of Scripture. There is impartiality before the law (Lv 24:22), rich and poor people are equal ( $\operatorname{Lv} 19: 15 ; \operatorname{Pr} 22: 2,29: 13)$ and the unequal treatment of individuals or populations is a violation of Godself ( $\operatorname{Pr} 14: 31 ; 17: 5 ; 19: 17)$. In the New Testament, Christ endorses the equality of people (Mt 5:43-45; Lorenzen 2009:288). Because human beings are image bearers of God, it is confirmed that equality is not an intrinsic characteristic of human beings, but a status which God grants them (Vorster 2011:177).

Without doubt, the deduction can be made that human dignity and equality as grounding principles also form powerful concepts in Protestant ethics. They constitute the foundation of non-discrimination and non-stigmatisation and therefore correlate with the same point of departure as found in the UDBHR.

Thirdly, closely related to the concepts of human dignity and equality, is the principle of non-discrimination. The bioethicist Macaleer (2014:237) states the point of departure, saying, "Thus, justice is grounded in the image of God, requiring equal treatment of all of those made in God's image." Being in the image of God implies that equal treatment is a positive value or the opposite of discrimination. Cheung-Judge (1995:313) is also of the opinion that being created in the image of God indicates equal treatment, and discrimination as unequal treatment. In the covenantal message of Job 31:15 and 34:19, a clear relation can be discerned between being in the image of God, equality and the prohibition of discrimination (Burridge 2011:235; Wright 1995:49-50). In the Old Testament covenant, it is shown that God's justice does not distinguish between people, because God is impartial (Dt 10:17; 2 Chr 19:7). In these Scripture sections, God does not consider the faces of people or their human characteristics; therefore, it is also expected of judges and leaders not to discriminate ( $\operatorname{Lv} 19: 15$; $\operatorname{Pr} 18: 5)$. In the New Testament, it is clearly stated that God acts impartially (Ac 10:34; 1 Pt 1:17), not taking into consideration the outward appearances of people (Gl 2:6).

According to Vorster (2017:217), non-discrimination can be grounded Christologically and pneumatologically based on Peter's message of salvation to all people and the fact that the Spirit was inclusively poured out on every person (Ac 2:17, 13:47). According to Burridge (2011:236), a Christological view of non-discrimination comprises the following: "However, Gal. 3:28 provides the clearest statement of nondiscrimination, which cuts across all ancient barriers: There is no longer Jew nor Greek, there is no longer slave or free, there is no longer male nor female: for all of you are one in Christ Jesus."

To be all one in Christ has the connotation of equality (Vorster 2007:198). The reference to Jew or Greek indicates that we may not discriminate based on race, culture or religion, exactly because God does not discriminate against people on these grounds (Rm 2:11). By "slave" or "free" Paul indicates that discrimination against people on the base of their social conditions is unacceptable, especially because God does not act in this way (Eph 6:9; Col 3:25). The use of the categories "man" or "woman" indicates that discrimination against people is not allowed on the grounds of their gender or sexuality, 
because God created all genders equally (Gn 1:27, 2:18; Ross 2011:720). Ross (2011:720) summarises the meaning of Galatians 3 (and Col 3:10-11) as follows: "Categories previously used to subject, discriminate, and unjustly favor some people are brought into the unifying work of Christ." With reference to the statement that the Spirit is given to all people, the Scripture states that the Spirit of God commanded Peter to meet the travel party sent by Cornelius "without doubt or hesitation" (Ac 10:20). The words

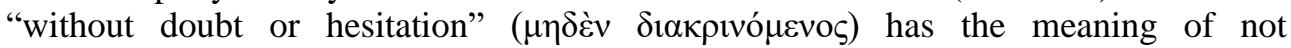
discriminating against people of other population groups (e.g. Italians) and other religious convictions (e.g. Jewish faith) by avoiding or not meeting them. The reason is precisely that God does not make a distinction between "they" and "us", between Jews and heathens (cf. Ac 11:12, 15:9; Burridge 2011:235).

The parable of the Good Samaritan (Lk 10:25-37:21) openly and clearly opposes discrimination in the context of health and carries an overpowering message that should be remembered: God's image should be sought and seen in the foreigner, the alien and the different (Du Rand 2017:121). The story affirms that a discriminatory attitude and actions based on class can harm the health of people, as when the Priest and Levite refused to help an injured man. On the other hand, an attitude and acts of nondiscrimination can promote health as seen in the actions of the Samaritan who cared for the injured man (Grudem 2018:loc. 16020).

It is clear that the principle of non-discrimination finds firm grounding in Protestant social ethics and therefore supports the appeal of the UDBHR to combat the practice of discrimination.

Fourth, Longchar (2011:413-414) connects the human being as the image of God, the equality of all people and non-stigmatisation with each other. The view is confirmed in the following explanation:

Stigma is sin because it denies the reality that we are created equally in the image of God (Gen. 1:27), that we are loved equally and unconditionally by God, and that we all have equal worth as bearers of the godly image. Because God ascribed dignity and equality to human beings in the work of creation, being made in the image of God speaks of the importance of equal and respectful relationships, indeed of reverence for all who bear the image, even if now only partially. Paul tells us that seeing the glory of God, we " ... are being transformed into the same image from one degree of glory to another; for this comes from the Lord, the Spirit" (2 Cor. 3:18). (Ackermann 2005:391)

God created all people in his image, which implies that God regards and treats all people as equals. God loves everyone equally and unconditionally and is good to everyone (Mt 5). Sex workers, men who have sex with men or drug users are given stigmatising names like "whores", "homos" "junkies", by which they are indicated as inferior to other people (who do not adhere to these lifestyles) and therefore do not deserve the same health care as other people. Because of stigmatisation, people do not receive the same unconditional love and equal worth. An appeal is made to the church to treat all people equally (Ac 2:47).

"This stigmatisation is against the very essence of the Christian message of love as it is evident from the life of Jesus himself", writes Vorster (2017:233). In the covenant of 
grace, Christ did indeed give special attention to and showed empathy with the marginalised and rejected people of his own society, for example lepers, the poor, prostitutes, the sick and tax collectors (Vorster 2017:197, 329). With reference to Vorster and his remark on lepers and the sick, it has to be pointed out that Jesus combated stigmatisation and accompanying discrimination as contradictory to the principles of the covenant of grace and love.

In explaining the meaning of Jesus touching a leper in Matthew 8, Viljoen (2014:3) says, "Leprosy was associated with uncleanness and a great social stigma was attached to it". It must be kept in mind that the word "leprous" could refer to all kinds of flaky and scaly skin diseases in several degrees of severity. In the Old Testament, in Leviticus 13:44-46, the prescriptions are found for a priest to pronounce a person as "leprous". The consequences of naming the "plague" was without doubt stigmatising. A leprous person was "unclean". Because of the threat of defiling other people, a leper was excluded from the community and all contact with others was prohibited. Lepers formed their own colonies and had to survive on their own ( $\operatorname{Lv} 13: 45-46 ; \mathrm{Nm} 5: 2-3)$. In contrast to the Old Testament, Jesus' actions point to the worthiness of the ill person in the covenant of grace. This is evident in the incident where he touched a leper, who was living under the stigmatising conditions of the law (Mt 8:3). Longchar (2011:412-416) emphasises that the reference to touching the leper is important, firstly because it shows that Jesus reached out to persons stigmatised by society and did not cast them aside or exclude them. Secondly, to my mind, it is clear that Jesus did not stigmatise a medical condition by labelling it with contemptuous names; when he addressed the leper, He only used the edifying words of healing. Thirdly, through healing and touching, the person was freed from further stigmatisation and social discrimination. The same is true of the sick woman who suffered from a discharge of blood and was therefore stigmatised as unclean (cf. Lv 15:26-27) and isolated from people (Mt 9:20-22). Jesus acknowledged that the woman had touched him and He would have known what the social implications of the incident would be (Longchar 2011:417): "In front of all his followers, Jesus declared her healed and cleansed. Jesus broke the social stigma. The social stigma associated with her due to her disease was nullified by his declaring, 'Go in peace' (Mark 5:34)."

To my mind, it might be disturbing, especially from a contemporary viewpoint, that the contemptuous naming in the Old Testament law was based on a medically related condition and that it resulted in characterising a person negatively. However, as Viljoen (2014:6) points out, with the emphasis on purity, which was symbolic of holiness, the "discrimination" against a leper as an impure or unholy person, was justified in the Old Testament covenant context. Nevertheless, Viljoen's conclusion can be accepted as a New Testament bioethical principle: “As the leper was purified, all Jesus' followers are purified. Boundaries of purity laws to categorise and isolate others are no longer applicable to them. Ritual purity becomes a moral category."

It is clear that the principle of non-stigmatisation finds powerful support in Protestant social ethics and therefore supports the appeal of the UDBHR against stigmatisation.

\section{Conclusion}

To date, there has been no official dialogue between UNESCO and the Protestant faith tradition regarding article 11 of the UDBHR; therefore, this article forms a first and 
preliminary introduction to the discussion. The purpose of this discussion is to formulate a theological ethical foundation for article 11 of the UDBHR. It is important from Protestant and UNESCO perspectives to formulate an ethical foundation. On the one hand, this conversation contributes to strengthening the credibility of the declaration, while on the other hand, a necessary religious status is offered to the instrument. It is clear that article 11 of the UDBHR states that non-discrimination and non-stigmatisation are two principles that have been accepted by the world community and should be promoted in the context of health. These two global bioethical principles are recognised and accepted by Protestant social ethics in the faith framework of the covenant and can therefore be promoted by the Protestant community in the context of health in South Africa and the world.

\section{BIBLIOGRAPHY}

Ackermann, D. 2005. Engaging stigma: An embodied theological response to HIV and Aids: The challenge of HIV/AIDS to Christian theology, Scriptura 89:385-395.

Bridger, F. 1995. Equality. In D.J. Atkinson, D. Field, A.F. Holmes and O. O'Donovan (eds), New dictionary of Christian ethics and pastoral theology. Downers Grove, Ill: InterVarsity Press.

Burridge, R. 2011. Discrimination. In D.J. Atkinson, D. Field, A.F. Holmes and O. O'Donovan (eds), New dictionary of Christian ethics and pastoral theology. Downers Grove, Ill: InterVarsity Press.

Cheung-Judge, L. 1995. Discrimination. In D.J. Atkinson, D. Field, A.F. Holmes and O. O'Donovan (eds), New dictionary of Christian ethics and pastoral theology. Downers Grove, Ill: InterVarsity Press.

Childress, J.F. 2002. Protestant perspectives on informed consent, particularly in research involving human participants, Fordham Urban Law Journal 30:87-206.

Douma, J. 1990. Ethiek en recht. Kampen: Van den Berg.

Douma, J. 1997. Medische ethiek. Kampen: Kok.

Duby, Z., Nkosi, B., Scheibe, A., Brown, B. and Bekker, L-G. 2018. Scared of going to the clinic: Contextualising healthcare access for men who have sex with men, female sex workers and people who use drugs in two South African cities, Southern African Journal of HIV Medicine 19(1), a701. Online: https://doi.org/10.4102/sajhivmed.v19i1.701 (Accessed: 28 April 2020).

Du Rand, J.A. 2017. How about the biblical GPS on our way to xenophilia instead of xenophobia. In J.A. du Rand, J.M. Vorster and N. Vorster (eds), Togetherness in South Africa. Cape Town: Aosis, pp. 107-135.

Gallagher, C.M. 2014. A Christian consideration of human vulnerability in healthcare and research. In Joseph Tham, Alberto Garcia and Gonzalo Miranda (eds), Religious perspectives on human vulnerability in bioethics. (Advancing global bioethics 2). Dordrecht: Springer.

Garrafa, V. 2016. Discrimination, Ethics of. In H. ten Have (ed.), Encyclopedia of global bioethics. Cham, Switzerland: Springer International Publishing.

Grudem, W. 2018. Christian ethics: An introduction to biblical moral reasoning. Wheaton, Ill: Crossway. 
Guessous, N. 2014. Non-discrimination and stigmatization. In H.A.M.J. ten Have and B. Gordijn (eds), Handbook of global bioethics. Dordrecht: Springer Science + Business Media.

Habermas, J. 1999. Bestiality and humanity: A war on the border between legality and morality, Constellations: An International Journal of Critical and Democratic Theory 6:263-272.

Habermas, J. 2012. Nachmetaphysisches Denken II: Aufsätze und Repliken. Berlin: Suhrkamp.

Higginson, R.A. 1995. Ethics of medical care. In D.J. Atkinson, D. Field, A.F. Holmes and O. O'Donovan (eds), New dictionary of Christian ethics and pastoral theology. Downers Grove, Ill: InterVarsity Press.

Hollinger, D.P. 2008. Choosing the good: Christian ethics in a complex world. Grand Rapids, Mich: Baker Academic.

IBC (International Bioethics Committee of UNESCO). 2005. Eleventh session, UNESCO headquarters, Paris, 23-24 August 2004. Report, L. de Castro. Online: https://wayback.archiveit.org/10611/20170616205821/http://unesdoc.unesco.org/images/0013/001395/13 9549e.pdf (Accessed: 18 November 2013).

http://unesdoc.unesco.org/images/0017/001781/178124e.pdf (Accessed: 18 November 2013).

IBC (International Bioethics Committee of UNESCO). 2010. Report on social responsibility and health. Online:

http://unesdoc.unesco.org/images/0018/001878/187899E.pdf (Accessed: 18 November 2013).

IBC (International Bioethics Committee of UNESCO). 2014. Report on the principle of non-discrimination and non-stigmatization. Paris: UNESCO.

Langlois, A. 2013. Negotiating bioethics: The governance of UNESCO's bioethics programme. New York, NY: Routledge.

Kelly, D., Magill, G. and Ten Have, H. 2013. Contemporary Catholic health care ethics. Washington, DC: Georgetown University Press.

König, A. 2010. Alle paaie lei na Jesus. Vereeniging: CUM.

Longchar, W. 2011. Unclean and compassionate hand of God, Ecumenical Review: World Council of Churches 63:408-418.

Lorenzen, T. 2009. Justice anchored in truth: A theological perspective on the nature and implementation of justice, International Journal of Public Theology 3:281-298.

Macaleer, R.D. 2014. The New Testament and bioethics: Theology and basic bioethics principles. Eugene, Oreg: Pickwick Publications.

Mackler, A. 2014. Judaism. In H.A.M.J. ten Have and B. Gordijn (eds), Handbook of global bioethics. Dordrecht: Springer Science + Business Media.

Morphew, D. 2015. Kingdom theology and human rights. Bergvliet: Author.

Nullens, P. and Volgers, R. 2010. Tussen 2 werelden: Een kennismaking met de Christelijke theologie. Almere: Coconut.

Osterhaven, M.E. 2017. Covenant theology. In Daniel J. Treier and Walter A. Elwell (eds), Evangelical dictionary of theology. (Kindle edition). Ada, Mich: Baker Publishing Group, pp. 215-216. 
Østnor, L., Hallamaa, J., Andersen, S., Björnssom, B., Nilsson, G. and Thunberg, L. 1995. The Lutheran approach to bioethics. In V. Mortensen (ed.), Life and death: Moral implications of biotechnology. Geneva: WCC Publications.

Pew Research Center. 2020. Global Christianity: A report on the size and distribution of the world's Christian population. Online: https://www.pewforum.org /2011 /12/19/ global-christianity-exec/ (Accessed: 10 February 2020).

Pirner, M.L. 2016a. Conclusion: Human rights and religion in educational contexts: Foundations and conceptional perspectives. In M.L. Pirner, J. Lähnemann and H. Bielefeldt (eds), Human rights and religion in educational contexts. (Interdisciplinary studies in human rights 1). Cham, Switzerland: Springer International, pp. 335-346.

Pirner, M.L. 2016b. Human rights, religions, and education: A theoretical framework. In M.L. Pirner, J. Lähnemann and H. Bielefeldt (eds), Human rights and religion in educational contexts. (Interdisciplinary studies in human rights 1). Cham, Switzerland: Springer International, pp. 11-27.

Rawls, J. 1993. Political liberalism. New York, NY: Columbia University Press. Rheeder, A.L. 2017a. Respect for cultural diversity as a global bioethical principle: Own reasons from a Protestant perspective, HTS Teologiese Studies/ Theological Studies 73(3), a4705. Online: https://doi.org/10.4102/hts.v73i3.4705.

Rheeder, A.L. 2017b. A global bioethical perspective on organ trafficking: Discrimination, stigmatisation and the vulnerable. S Afr J Bioethics Law 10(1):2024. DOI: 10.7196/SAJBL.2017.v10i1.528. Online: https://www.ajol.info/index.php/sajbl/article/view/158663.

Rheeder, R. 2018. Solidarity as a global bioethical principle: Own reasons for a culture of solidarity from a Protestant perspective, Verbum et Ecclesia 39(1), a1816. Online: https://doi.org/ 10.4102/ve.v39i1.1816.

Rheeder, A.L. 2019a. Benefit-sharing as a global bioethical principle: A participating dialogue grounded on a Protestant perspective on fellowship, In die Skriflig 53(1), a2502. Online: https://doi.org/10.4102/ids. v53i1.2502.

Rheeder, A.L. 2019b. Social responsibility for health as a global bioethical principle: A Protestant participation in the discussion with UNESCO, Stellenbosch Theological Journal 5(1):317-346. Online: doi: tp://dx.doi.org/10.17570/stj.2019.v5n1.a15.

Rivard, G. 2009. Article 11: Non-discrimination and non-stigmatization. In H. ten Have and M. Jean (eds), The UNESCO universal declaration on bioethics and human rights: Background, principles and application. (Ethics series). Paris: UNESCO Publishing.

Ross, C. 2011. Sex discrimination. In J.B. Green, J.E. Lapsley, R. Miles and A. Verhey (eds), Dictionary of Scripture and ethics. Grand Rapids, Mich: Baker Academic.

Rusthoven, J.J. 2014. Covenantal biomedical ethics for contemporary medicine: An alternative to principles-based ethics. Eugene, Oreg: Wipf \& Stock Publishers.

SAHRC (South African Human Rights Commission). 2018. Ensuring health and access to health care for migrants: A right and good public health practice. Online: https://www.sahrc.org.za/index.php/sahrc-media/opinionpieces/item/1422-ensuring-health-and-access-to-health-care-for-migrants-a-rightand-good-public-health-practice (Accessed: 5 July 2020). 
Taylor, C. 2007. A secular age. Cambridge, Mass: Belknap Press of Harvard University Press.

Ten Have, H. 2016. Global bioethics: An introduction. Abingdon, UK: Routledge.

Ten Have, H. and Jean, M. 2009. Introduction. In H. ten Have and M. Jean (eds), The UNESCO universal declaration on bioethics and human rights: Background, principles and application. (Ethics series). Paris: UNESCO Publishing.

Tham, J. 2014. Introduction: The principle of vulnerability: Meeting ground of six religions. In Joseph Tham, Alberto Garcia and Gonzalo Miranda (eds), Religious perspectives on human vulnerability in bioethics. (Advancing global bioethics 2). Dordrecht: Springer.

Tham, J. 2017. Lessons learned. In J. Tham, K.M. Kwan and A. Garcia (eds), Religious perspectives on bioethics and human rights. (Advancing global bioethics 6). New York, NY: Springer International Publishing, pp. 279-291. Online: doi: 10.1007/978-3-319-58431-7 (Accessed: 10 February 2020).

Tham, J., Durante, C. and Gómez, A.G. 2018. Religious perspectives on social responsibility in health: Towards a dialogical approach. (Advancing global bioethics 2). Dordrecht: Springer. Online: doi: 10.1007/978-94-017-8736-9 (Accessed: 10 February 2020).

UNESCO. 2003. International declaration on human genetic data. Online: http://portal.unesco.org/en/ev.phpURL_ID=17720\&URL_DO=DO_TOPIC\&URL_SECTION=201.html (Accessed: 20 November 2016).

UNESCO. 2006. Universal declaration on bioethics and human rights. Online: http://unesdoc.unesco.org/images/0014/001461/146180e.pdf (Accessed: 18 November 2013).

UNESCO. 2008. Bioethics core curriculum, Section 1: Syllabus ethics education programme sector for social and human sciences, Division of Ethics of Science and Technology. Online:

http://unesdoc.unesco.org/images/0016/001636/163613e.pdf (Accessed: 18 November 2013).

UNESCO. 2011. Casebook on human dignity and human rights, Bioethics core curriculum (Casebook series 1). Online: http://unesdoc.unesco.org/images/0019/001923/192370e.pdf (Accessed: 18 November 2013).

UNESCO. 2019. Universal declaration on bioethics and human rights. Online: https://en.unesco.org/themes/ethics-science-and-technology/bioethics-and-humanrights (Accessed: 10 February 2020).

United Nations. 1965. International convention on the elimination of all forms of racial discrimination, 21 December. Online: http://www.supremecourt.ge/files/uploadfile/pdf/act6.pdf (Accessed: 21 November 2016).

United Nations. 1979. Convention on the elimination of all forms of discrimination against women. Online: http://www.ohchr.org/Documents/ProfessionalInterest/cedaw.pdf (Accessed: 21 November 2016).

VanDrunen, D. 2009. Bioethics and the Christian life: A guide to making difficult decisions. Wheaton, Ill: Crossway. 
Van Leeuwen, E. 2014. Protestantism. In H.A.M.J. ten Have and B. Gordijn (eds), Handbook of global bioethics. Dordrecht: Springer Science + Business Media.

Van Wyk, J.H. 1991. Etiek en mensregte, moraliteit en verantwoordelikheid: Opstelle oor politieke etiek. Potchefstroom: Dept. Sentrale Publikasies, PU vir CHO.

Van Wyk, J. H. 1998. Debat oor menseregte, etiek in eenvoud: Gesprekke oor morele vraagstukke. Noordbrug: Potchefstroomse Teologiese Publikasies.

Viljoen, F.P. 2014. Jesus healing the leper and the purity law in the Gospel of Matthew, In Verbum Luce 48 (2)1. Online: doi.org/10.4102/ ids.v48i2.1751 (Accessed: 10 March 2019).

Vorster, J.M. 2007. Christian attitude in the South African liberal democracy. Potchefstroom: Potchefstroom Theological Publications.

Vorster, J.M. 2015. Christelike etiek in 'n sekulariserende samelewing. Durbanville, South Africa: AOSIS.

Vorster, J.M. 2017. Ethical perspectives on human rights. Potchefstroom: Potchefstroom Theological Publications.

Vorster, N. 2007. Restoring human dignity in South Africa: Christian anthropology in a new dispensation. Potchefstroom: Potchefstroom Theological Publications.

Vorster, N. 2011. Created in the image of God: Understanding God's relationship with humanity. Eugene, Oreg: Pickwick.

Wright, C. 1995. Old Testament ethics. In D.J. Atkinson, D. Field, A.F. Holmes and O. O'Donovan (eds), New dictionary of Christian ethics and pastoral theology. Downers Grove, Ill: InterVarsity Press. 